\title{
Clay-Magnetite Co-Aggregates for Efficient Magnetic Removal of Organic and Inorganic Pollutants
}

\author{
Eliana Pecini and Marcelo Avena * (D) \\ INQUISUR, Departamento de Química, Universidad Nacional del Sur (UNS)-CONICET, \\ 8000 Bahía Blanca, Argentina; eliana.pecini@uns.edu.ar \\ * Correspondence: mavena@uns.edu.ar
}

Citation: Pecini, E.; Avena, M Clay-Magnetite Co-Aggregates for Efficient Magnetic Removal of Organic and Inorganic Pollutants. Minerals 2021, 11, 927. https:// doi.org/10.3390/min11090927

Academic Editors: Jorge César Masini and Gilberto Abate

Received: 23 July 2021

Accepted: 25 August 2021

Published: 27 August 2021

Publisher's Note: MDPI stays neutral with regard to jurisdictional claims in published maps and institutional affiliations.

\begin{abstract}
This work reports the behavior of montmorillonite-magnetite mixtures of varying composition in aqueous dispersions and evaluates their adsorbing properties using a cationic organic pollutant, methylene blue $\left(\mathrm{MB}^{+}\right)$, and an anionic inorganic pollutant, arsenate $(\mathrm{As}(\mathrm{V}))$, as the adsorbing species. The effects of the presence of montmorillonite on the $\mathrm{As}(\mathrm{V})$ adsorption by magnetite and the effects of magnetite on the $\mathrm{MB}^{+}$adsorption by the clay were specially addressed. The simple mixture of a montmorillonite dispersion with a magnetite dispersion led to the spontaneous formation of montmorillonite-magnetite co-aggregates. These co-aggregates showed a unimodal electrophoretic mobility distribution, with no evidence of the presence of separate populations of montmorillonite or magnetite. The application of a magnetic field confirmed the formation of co-aggregates and showed that their separation rate increased as the magnetite content increased. Adsorption studies as a function of the aggregate composition demonstrated that $\mathrm{MB}^{+}$uptake was mainly controlled by the content of montmorillonite, while $\mathrm{As}(\mathrm{V})$ adsorption was mainly controlled by the content of $\mathrm{Fe}_{3} \mathrm{O}_{4}$. This permits an easy tuning of the adsorbing properties of cations and anions by controlling the composition of the system.
\end{abstract}

Keywords: remediation; magnetic clays; particle aggregates

\section{Introduction}

Extensive research has been carried out in the field of environmental remediation in the last decades, aiming to develop efficient, economical, and versatile water remediation technologies. In this context, magnetic separation has been applied recently in many areas for preconcentration and quantification in analytical chemistry [1,2], to capture and separate pollutants from aqueous environments $[3,4]$, and to adsorb and degrade undesired substances [5]. These technologies are inexpensive, reliable, fast, and durable to treat wastewater and, if well adapted, would allow to remove specific contaminants from water. Therefore, magnetic modification of inexpensive adsorbents, such as clays, can lead to the formation of magnetic particles that can be easily and rapidly removed from solutions by applying an external magnetic field [5,6], capturing organic and inorganic pollutants.

Clays, such as montmorillonite, have been used since the beginning of civilization and have maintained their position among the most important industrial raw materials since then. They are well known as adsorbents not only of heavy metals, but also of drugs, pesticides, organic matter, etc. [7-11] On the other hand, magnetic nanoparticles, such as $\mathrm{Fe}_{3} \mathrm{O}_{4}$, have generated considerable repercussion in adsorption technologies and, consequently, in the remediation field [12,13], due to their stability, large surface area, high number of surface active sites, and, unlike montmorillonite which is paramagnetic, the particular advantage of being able to be separated by applying an external magnetic field.

Montmorillonite and magnetite surfaces behave differently in aqueous media. In the case of montmorillonite, most of the surface contains siloxane groups, which are not involved in protonation-deprotonation reactions. Therefore, the charge of montmorillonite 
particles is dominated by negative structural charges, arising from isomorphic substitutions, making montmorillonite a good adsorbent of cationic species through a cation exchange mechanism. In the case of magnetite, surface hydroxyl groups coordinated to Fe(III) and $\mathrm{Fe}(\mathrm{II})$ ions at the surface have the capacity to protonate or deprotonate depending on the $\mathrm{pH}$, resulting in positive charges at low $\mathrm{pH}$ and negative charges at high $\mathrm{pH}$. In addition, these hydroxyl groups can be exchanged by anionic ligands such as arsenate; thus, magnetite can adsorb anionic moieties via a ligand exchange mechanism.

The differences in the surface properties of both solids indicate that the preparation of aggregates consisting of a mixture of montmorillonite and magnetite particles will lead to a system with the capacity to adsorb cationic and anionic pollutants, whether organic or inorganic. Furthermore, the presence of magnetite in each aggregate will impart magnetic properties to them, enabling the separation of the aggregates with an external magnetic field, making them extremely useful in adsorption and remediation processes.

Currently, there are works in the literature where the properties of the montmorillonitemagnetite system have been explored. Galindo-Gonzales et al. [14] synthesized magnetitecovered clay particles in aqueous medium, but they did not carry out adsorption studies. The work focused on the sedimentation behavior of monodisperse magnetic particles, for application in the formulation of magnetorheological fluids. Mamedov et al. [15] synthesized thin films of magnetite-montmorillonite and polyelectrolytes, as well as measured their optical and magnetic properties, but they did not carry out adsorption studies. Yuan et al. [16] and Larraza et al. [17] were seemingly the first to specifically show adsorption studies of an anion (chromate) in montmorillonite-magnetite composite systems, demonstrating their good adsorbent properties. Some works in which clay-magnetite nanoparticle systems [18] were used as enzyme support have also been published [19], while others reported their good cation adsorption properties using $\mathrm{Ni}^{2+}, \mathrm{Cu}^{2+}, \mathrm{Cd}^{2+}$, and $\mathrm{Zn}^{2+}[20]$.

Most of the studies dealing with adsorption using clay-magnetite systems focused on studying the adsorption of a particular species, whether anionic or cationic. There are no reports in the literature exploring the ability of these systems to adsorb both anions and cations. Such a kind of adsorbent would be technologically sound, since the same solid will be capable of removing a great variety of pollutants.

The aim of this work was to evaluate the adsorptive properties of montmorillonitemagnetite co-aggregates, prepared in different proportions of clay and oxide. A well-known cationic die, methylene blue $\left(\mathrm{MB}^{+}\right)$, and well-known anionic species such as $\mathrm{As}(\mathrm{V})$ species in aqueous media were used to test the properties of the adsorbents. The electrokinetic and magnetic properties of the co-aggregates are also reported. The effects of the presence of one solid on the adsorptive properties of the other solid in the co-aggregates were evaluated.

\section{Materials and Methods}

\subsection{Materials}

$\mathrm{FeCl}_{2} \cdot 4 \mathrm{H}_{2} \mathrm{O}, \mathrm{FeCl}_{3} \cdot 6 \mathrm{H}_{2} \mathrm{O}, \mathrm{K}_{2} \mathrm{HAsO}_{4} \cdot 7 \mathrm{H}_{2} \mathrm{O}$, and methylene blue (in a chloride salt form) were obtained from Merck (Germany). $\mathrm{KCl}, \mathrm{KOH}$, and $\mathrm{HCl}$ were purchased from Anhedra (Argentina). All chemicals were of analytical grade and were used as received. Double-distilled water was used in all cases.

The montmorillonite (Mt) studied in this work came from the Northern Patagonia, in Argentina. Lombardi et al. [21] described its chemical composition and physicochemical properties (identified as sample 4 in the article). The material, mostly composed of montmorillonite (98\% purity), with low amounts of gypsum and quartz, presented a cation exchange capacity (CEC) of $0.96 \mathrm{meq} \cdot \mathrm{g}^{-1}$ (measured using the standard ammonium acetate method) and a specific surface area of $738 \mathrm{~m}^{2} \cdot \mathrm{g}^{-1}$ (determined by water adsorption) [21]. Particles with nominal diameter $<2 \mu \mathrm{m}$ were obtained by sedimentation, and a homoionic Na-montmorillonite was prepared by dispersing suitable amounts of the solid several times in a $1 \mathrm{M} \mathrm{NaCl}$ solution. Afterward, the sample was washed with $0.01 \mathrm{M} \mathrm{NaCl}$ (successive centrifugal treatments) until the conductivity of the supernatant was equal to 
that of the washing solution. A final stock suspension of $12.8 \mathrm{~g} \cdot \mathrm{L}^{-1}$ was obtained after these treatments.

The magnetic particles $\left(\mathrm{Fe}_{3} \mathrm{O}_{4}\right)$ were synthesized via chemical coprecipitation, as indicated elsewhere [22]. A stock suspension was also prepared after synthesis and washing, with a concentration of $7.52 \mathrm{~g} \cdot \mathrm{L}^{-1}$. The physicochemical and adsorptive properties of the studied $\mathrm{Fe}_{3} \mathrm{O}_{4}$ particles were reported in a previous publication [22]. They showed superparamagnetic properties, spherical shape, and an average size of $12 \mathrm{~nm}$.

From the montmorillonite and magnetite stock suspensions, a series of montmorillonitemagnetite mixtures $\left(\mathrm{Mt}-\mathrm{Fe}_{3} \mathrm{O}_{4}\right)$ were prepared. The following mass fractions $(\mathrm{F})$ were obtained: $0.20,0.27,0.44,0.60$, and 0.85 , defining this relationship as

$$
F=\frac{\mathrm{m}_{\mathrm{Fe}_{3} \mathrm{O}_{4}}}{\mathrm{~m}_{\mathrm{Mt}}+\mathrm{m}_{\mathrm{Fe}_{3} \mathrm{O}_{4}}},
$$

where $\mathrm{m}_{\mathrm{Fe}_{3} \mathrm{O}_{4}}$ and $\mathrm{m}_{\mathrm{Mt}}$ are the masses in grams of magnetite and montmorillonite, respectively. The different $\mathrm{Mt}-\mathrm{Fe}_{3} \mathrm{O}_{4}$ mixtures, with a concentration of $5.0 \mathrm{~g} \cdot \mathrm{L}^{-1}$, were kept in suspension at room temperature. These mixtures are called $\mathrm{Mt}-\mathrm{Fe}_{3} \mathrm{O}_{4}(\mathrm{~F})$, using the corresponding value of $F$ within parentheses.

\subsection{XRD, FT-IR, and Zeta Potential}

The pure solids and the mixtures were examined by XRD using a Rigaku D-Max III-C instrument equipped with a $\mathrm{Cu}-\mathrm{K}_{\alpha 1}(\lambda=1.54059 \AA)$ source and a graphite monochromator operated at $35 \mathrm{kV}$ and $15 \mathrm{~mA}$ over the $2 \theta$ range $3-80^{\circ}$ at a scan rate of $0.02^{\circ}(2 \theta) \mathrm{s}^{-1}$.

FT-IR spectra of all samples were recorded with a Nicolet FT-IR Nexus 470 spectrophotometer in the range $400-4000 \mathrm{~cm}^{-1}$ using the $\mathrm{KBr}$ pellet technique.

The electrophoretic mobilities at $25^{\circ} \mathrm{C}$ of $\mathrm{Mt}, \mathrm{Fe}_{3} \mathrm{O}_{4}$, and $\mathrm{Mt}-\mathrm{Fe}_{3} \mathrm{O}_{4}$ mixtures were measured using a Malvern Zetasizer Nano ZS 90 equipment. The zeta potential ( $\zeta$ ) was automatically calculated with the classic Smoluchowski equation. Studies were performed as a function of $\mathrm{pH}$ using $0.01 \mathrm{M} \mathrm{KCl}$ as supporting electrolyte. For each sample, $50 \mathrm{~mL}$ of a $0.1 \mathrm{~g} \cdot \mathrm{L}^{-1}$ suspension in $0.01 \mathrm{M} \mathrm{KCl}$ were placed in a reaction cell, under continuous stirring. The $\mathrm{pH}$ was lowered to a value around 3.5 with $\mathrm{HCl}$, and $\mathrm{N}_{2}$ was bubbled for $30 \mathrm{~min}$. Once the suspension was stabilized, $\zeta$ was measured. The $\mathrm{pH}$ was then increased with small additions of $\mathrm{KOH}$, and $\zeta$ was again measured. This procedure was repeated until the $\mathrm{pH}$ was around 9.5.

For selected cases, the zeta potential distribution was measured. This is important for mixtures because the obtained distribution can give valuable information regarding the presence of one, two, or even more populations of particles or aggregates with different electrokinetic properties. During a default $\zeta$ measurement, the equipment determined two outcomes in separate. On the one hand, the mean value of $\zeta$ was obtained from a fast field reversal measurement. On the other hand, the $\zeta$ distribution was obtained from the combination of slow and fast field reversal application. In this way, the zeta potential distribution is an interpretation of potential contributions from differently charged particles that could have contributed to the result.

\subsection{Adsorption Studies}

Adsorption studies were performed with $\mathrm{Mt}, \mathrm{Fe}_{3} \mathrm{O}_{4}$, and $\mathrm{Mt}-\mathrm{Fe}_{3} \mathrm{O}_{4}$ mixtures. $\mathrm{MB}^{+}$ and $\mathrm{As}(\mathrm{V})$ adsorption isotherms were carried out at $\mathrm{pH} 7$ in $0.01 \mathrm{M} \mathrm{KCl}$ using $15 \mathrm{~mL}$ polyethylene centrifuge tubes. For the case of $\mathrm{MB}^{+}$adsorption on $\mathrm{Mt}, 0.100 \mathrm{~mL}$ of the montmorillonite stock suspension $\left(\mathrm{m}_{\mathrm{Mt}}=1.28 \times 10^{-3} \mathrm{~g}\right)$ was mixed with the desired volume of $0.001 \mathrm{M} \mathrm{MB}^{+}$, and then $0.01 \mathrm{M} \mathrm{KCl}$ was added to reach a final volume of $10 \mathrm{~mL}$. For the case of $\mathrm{As}(\mathrm{V})$ adsorption on $\mathrm{Mt}$, an analogous procedure was followed, but using the desired volumes of a $0.001 \mathrm{M} \mathrm{As}(\mathrm{V})$ solution. The final volume was also set to $10 \mathrm{~mL}$ with $0.01 \mathrm{M} \mathrm{KCl}$. The same procedure was applied for the cases of $\mathrm{MB}^{+}$ and $\mathrm{As}(\mathrm{V})$ adsorption on $\mathrm{Fe}_{3} \mathrm{O}_{4}$. In these cases, $1.00 \mathrm{~mL}$ of the $\mathrm{Fe}_{3} \mathrm{O}_{4}$ stock suspension 
$\left(\mathrm{m}_{\mathrm{Fe}_{3} \mathrm{O}_{4}}=7.52 \times 10^{-3} \mathrm{~g}\right)$ was used, and varying volumes of either $0.001 \mathrm{M} \mathrm{MB}^{+}$(from 0.100 a $2.00 \mathrm{~mL}$ ) or $0.001 \mathrm{M} \mathrm{As}(\mathrm{V})$ (from 0.100 to $2.00 \mathrm{~mL}$ ) were added.

In order to investigate the effect of the composition of $\mathrm{Mt}-\mathrm{Fe}_{3} \mathrm{O}_{4}$ mixtures (different $\mathrm{F}$ values) on $\mathrm{MB}^{+}$and $\mathrm{As}(\mathrm{V})$ adsorption, two sets of tubes were prepared. In the first case, centrifuge tubes containing a constant amount of $\mathrm{Mt}\left(\mathrm{m}_{\mathrm{Mt}}=1.28 \times 10^{-3} \mathrm{~g}\right)$ and increasing amounts of $\mathrm{Fe}_{3} \mathrm{O}_{4}$ stock suspension, yielding the $\mathrm{F}$ values of 0 (pure $\mathrm{Mt}$ ), 0.20, $0.27,0.44,0.60,0.85$, and 1 (pure $\mathrm{Fe}_{3} \mathrm{O}_{4}$ ), were sonicated for $5 \mathrm{~min}$. Later, a fixed amount of $\mathrm{MB}^{+}(2.00 \mathrm{~mL}$ of $0.001 \mathrm{M}$ solution) was added to each tube. In the second case, centrifuge tubes containing a constant amount of $\mathrm{Fe}_{3} \mathrm{O}_{4}\left(\mathrm{~m}_{\mathrm{Fe}_{3} \mathrm{O}_{4}}=7.52 \times 10^{-3} \mathrm{~g}\right)$ and increasing amounts of Mt stock suspension were also sonicated for $5 \mathrm{~min}$, and a fixed amount of As(V) (1.60 mL of $0.001 \mathrm{M}$ solution) was added. In both sets of tubes, the final volume was set to $10.00 \mathrm{~mL}$ with $0.01 \mathrm{M} \mathrm{KCl}$.

Lastly, three mixtures were selected to perform adsorption isotherms: $\mathrm{Mt}-\mathrm{Fe}_{3} \mathrm{O}_{4(0.20)}$, $\mathrm{Mt}-\mathrm{Fe}_{3} \mathrm{O}_{4(0.60)}$, and $\mathrm{Mt}-\mathrm{Fe}_{3} \mathrm{O}_{4(0.85)}$, where the values within parentheses denote the value of $\mathrm{F}$ in each mixture. The $\mathrm{pH}$ was 7 , the final volume was $10 \mathrm{~mL}$, and the ionic strength was controlled by $0.01 \mathrm{M} \mathrm{KCl}$. The operational conditions concerning these isotherms are detailed in the Supplementary Materials (Tables S1-S6).

In all the adsorption experiments previously described, the tubes were shaken for $24 \mathrm{~h}$ and centrifuged, and the concentration of $\mathrm{MB}^{+}$or $\mathrm{As}(\mathrm{V})$ remaining in the supernatant was quantified. The adsorbed amount was calculated from the difference between the initial concentration and the concentration that remained in the supernatant. $\mathrm{MB}^{+}$was spectrophotometrically measured by recording the UV/vis spectra in the 200-800 wavelength range reading the absorbance at $664 \mathrm{~nm}$ [23]. Arsenate was quantified by the spectrophotometric molybdenum blue method validated by Lenoble et al. [24] for arsenic species in aqueous media.

\section{Results and Discussion}

\subsection{XRD, FT-IR, Zeta Potential, and Magnetic Remotion}

Figure 1 shows the $\mathrm{X}$-ray diffractograms of $\mathrm{Fe}_{3} \mathrm{O}_{4}, \mathrm{Mt}$ (raw material, before sedimentation to obtain the $<2 \mu \mathrm{m}$ fraction), a physical mixture of raw $\mathrm{Mt}$ and $\mathrm{Fe}_{3} \mathrm{O}_{4}$ powders $(\mathrm{F}=0.60)$, and $\mathrm{Mt}-\mathrm{Fe}_{3} \mathrm{O}_{4(0.60)}$. The pattern of $\mathrm{Fe}_{3} \mathrm{O}_{4}$ matched that of magnetite samples from the literature (ICDD: 00-019-0629), exhibiting the characteristics peaks at $30.2^{\circ}(220)$, $35.2^{\circ}(311), 43.2^{\circ}(400), 53.7^{\circ}(422), 57.1^{\circ}(511)$, and $62.7^{\circ}(440)$. The pattern of Mt showed three characteristic reflections at $7.12^{\circ}(001), 19.80^{\circ}(02-11), 28.78^{\circ}(004)$. Montmorillonite is a layered aluminosilicate mineral, where each layer is formed by two tetrahedral sheets sandwiching an octahedral sheet. The layers pile up forming stacks, where each layer is separated from the other by the interlayer or interlaminar spacing, which contains water and intercalated cations [23]. The basal spacing, $\mathrm{d}_{001}=12.70 \AA$, corresponds to the sum of the interlaminar spacing (variable thickness, depending on the size of the intercalated species and hydration) and the thickness of the Mt layer (constant, $9.6 \AA$ ), indicating that the interlaminar space was $3.1 \AA$, typical of a sodium montmorillonite with a monolayer of water in the interlaminar region $[25,26]$. There were also some reflections due to the presence of quartz and gypsum in this raw sample. The physical mixture of raw Mt and $\mathrm{Fe}_{3} \mathrm{O}_{4}$ powders showed all the reflections of raw $\mathrm{Mt}$ and magnetite. However, in the pattern of $\mathrm{Mt}-\mathrm{Fe}_{3} \mathrm{O}_{4(0.60)}$, only the characteristic reflections of $\mathrm{Fe}_{3} \mathrm{O}_{4}$ could be observed. The absence of quartz and gypsum reflections was expected because $\mathrm{Mt}-\mathrm{Fe}_{3} \mathrm{O}_{4(0.60)}$ was prepared with Mt after sedimentation and homoionization, but the absence of the (001) and (004) reflections of Mt, suggests changes in the stacking or piling of Mt layers with, perhaps, some delamination due to the presence of magnetite. 


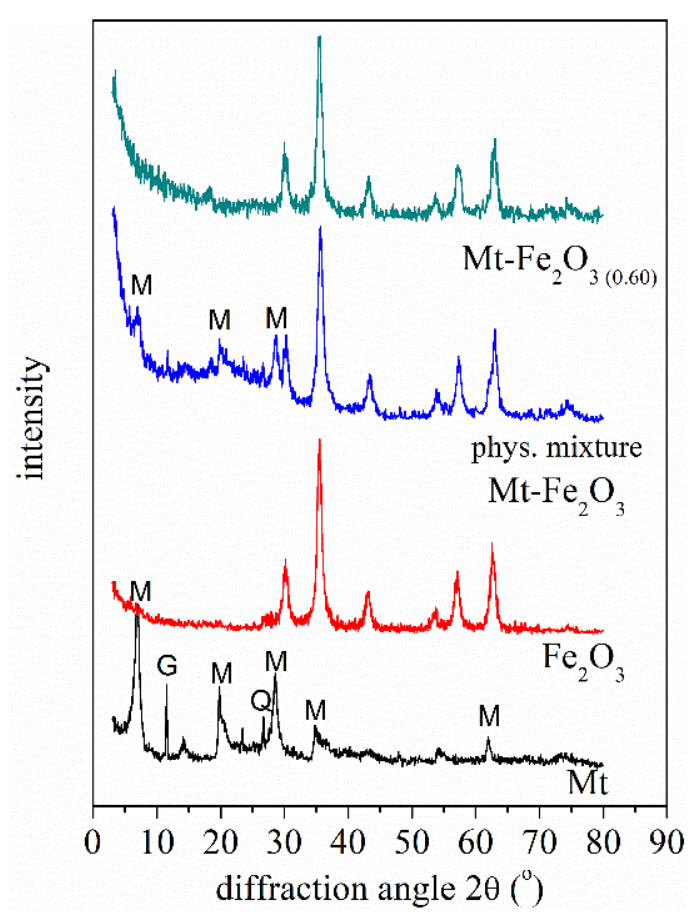

Figure 1. X-ray diffraction data of raw $\mathrm{Mt}, \mathrm{Fe}_{3} \mathrm{O}_{4}$, a physical mixture of raw $\mathrm{Mt}$ and $\mathrm{Fe}_{3} \mathrm{O}_{4}$ powders $(\mathrm{F}=0.60)$, and $\mathrm{Mt}-\mathrm{Fe}_{3} \mathrm{O}_{4(0.60)}$. The reflections of montmorillonite $(\mathrm{M})$, gypsum $(\mathrm{G})$, and quartz $(\mathrm{Q})$ are indicated in the Mt diffractogram. The reflections of montmorillonite are also indicated in the diffractogram of the physical mixture.

The FT-IR spectra of $\mathrm{Mt}, \mathrm{Fe}_{3} \mathrm{O}_{4}$, and $\mathrm{Mt}-\mathrm{Fe}_{3} \mathrm{O}_{4}(0,60)$ are shown in Figure 2. The clay spectrum exhibited its characteristic absorption bands. The band at $3627 \mathrm{~cm}^{-1}$ corresponds to the stretching vibration of the $\mathrm{OH}$ groups linked to the cations of the octahedral layer. This band is typical of smectites where most of the octahedral sites are occupied by $\mathrm{Al}^{3+}$ atoms [27]. The broad band at $3444 \mathrm{~cm}^{-1}$ corresponds to $\mathrm{OH}$ groups that participate in hydrogen bonding. The band at $1646 \mathrm{~cm}^{-1}$ belongs to the deformation of the $\mathrm{OH}$ groups of the hydration water of montmorillonite. The band at $1041 \mathrm{~cm}^{-1}$ results from the stretching of $\mathrm{Si}-\mathrm{O}$ bond of $\mathrm{Si}^{4+}$ present in the tetrahedral sheets, together with a small "shoulder" that appears around $1100 \mathrm{~cm}^{-1}$ due to the vibration of $\mathrm{Al}^{3+}$ that is replacing $\mathrm{Si}^{4+}$ in the tetrahedral sheet. The band at $914 \mathrm{~cm}^{-1}$ is related to the deformation vibration of the $\mathrm{OH}$ groups with $\mathrm{Al}$ present in octahedral position [28]. Two bands at $883 \mathrm{~cm}^{-1}$ and $843 \mathrm{~cm}^{-1}$ were attributed to the deformation of the $\mathrm{OH}$ group with partial substitution of octahedral $\mathrm{Al}^{3+}$ by $\mathrm{Fe}^{2+}$ and $\mathrm{Mg}^{2+}$, respectively. The low intensity of the bands indicates low content of octahedral $\mathrm{Fe}^{2+}$ and $\mathrm{Mg}^{2+}$ [29]. Lastly, two sharp bands of equivalent intensity appeared at $520 \mathrm{~cm}^{-1}$ and $464 \mathrm{~cm}^{-1}$, corresponding to deformation vibrations of the $\mathrm{Si}-\mathrm{O}-\mathrm{Al}$ bond (where $\mathrm{Al}^{3+}$ is the octahedral cation) and $\mathrm{Si}-\mathrm{O}-\mathrm{Si}$ bond, respectively [30]. The FT-IR spectrum of magnetite particles showed a broad band at $3400 \mathrm{~cm}^{-1}$, typical for symmetric and asymmetric vibrations of $\mathrm{OH}$ groups. The band at $1644 \mathrm{~cm}^{-1}$ was attributed to the $\mathrm{O}-\mathrm{H}$ bending vibration of water, and the bands at $581 \mathrm{~cm}^{-1}$ and $440 \mathrm{~cm}^{-1}$ were attributed to the $\mathrm{Fe}-\mathrm{O}$ stretching vibrations in tetrahedral and octahedral positions, respectively [31]. The $\mathrm{Mt}-\mathrm{Fe}_{3} \mathrm{O}_{4}(0,60)$ spectrum was a superposition of montmorillonite bands with those of magnetite. No clear evidence of new bands indicating the existence of a new chemical bond or a new phase appeared. The IR spectra of the other mixtures, which are not shown here for simplicity, showed the same characteristics. 


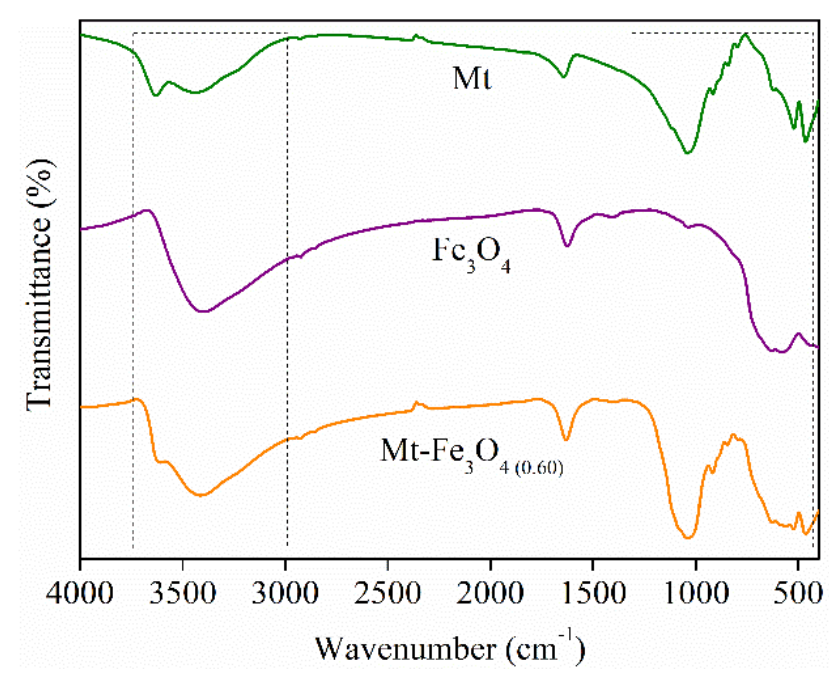

Figure 2. IR spectra of selected samples.

Figure 3 shows the electrokinetic behavior of $\mathrm{Mt}, \mathrm{Fe}_{3} \mathrm{O}_{4}$, and the $\mathrm{Mt}-\mathrm{Fe}_{3} \mathrm{O}_{4}$ mixtures at different $\mathrm{pH}$. In the case of $\mathrm{Mt}, \zeta$ was dominated by the negative structural charge of the clay mineral, being negative throughout the entire $\mathrm{pH}$ range studied, with nearly constant values around $-40 \mathrm{mV}$. This behavior is well known and has been reported several times in the literature [32-34]. $\mathrm{Fe}_{3} \mathrm{O}_{4}$ particles exhibited a different behavior, showing an isoelectric point (IEP) of 7.8, with positive $\zeta$ at $\mathrm{pH}<$ IEP and negative $\zeta$ at $\mathrm{pH}>$ IEP, as a result of protonation-deprotonation reactions of the surface groups [35,36]. All $\mathrm{Mt}-\mathrm{Fe}_{3} \mathrm{O}_{4}$ mixtures presented negative $\zeta$ in the entire $\mathrm{pH}$ range studied. Those mixtures with low magnetite contents ( $\mathrm{Mt}-\mathrm{Fe}_{3} \mathrm{O}_{4(0.20)}, \mathrm{Mt}-\mathrm{Fe}_{3} \mathrm{O}_{4(0.27)}$, and $\left.\mathrm{Mt}-\mathrm{Fe}_{3} \mathrm{O}_{4(0.44)}\right)$ had a nearly constant $\zeta$, almost independent of $\mathrm{pH}$, as with $\mathrm{Mt}$. Mixtures with high magnetite content showed a detectable $\mathrm{pH}$ dependence of $\zeta$, with this dependence being less marked for $\mathrm{Mt}-\mathrm{Fe}_{3} \mathrm{O}_{4(0.60)}(\zeta$ changed from $-30 \mathrm{mV}$ at $\mathrm{pH} 3.5$ to $-40 \mathrm{mV}$ at $\mathrm{pH}$ 9.5) than for $\mathrm{Mt}-\mathrm{Fe}_{3} \mathrm{O}_{4(0.85)}(\zeta$ changed from $-16 \mathrm{mV}$ at $\mathrm{pH} 3.5$ to $-40 \mathrm{mV}$ at $\mathrm{pH} 9.5)$. In summary, the behavior of the mixtures was in between the behavior of $\mathrm{Mt}$ and $\mathrm{Fe}_{3} \mathrm{O}_{4}$, with a marked influence of $\mathrm{Mt}$, since no mixture acquired positive mobilities at any $\mathrm{pH}$.

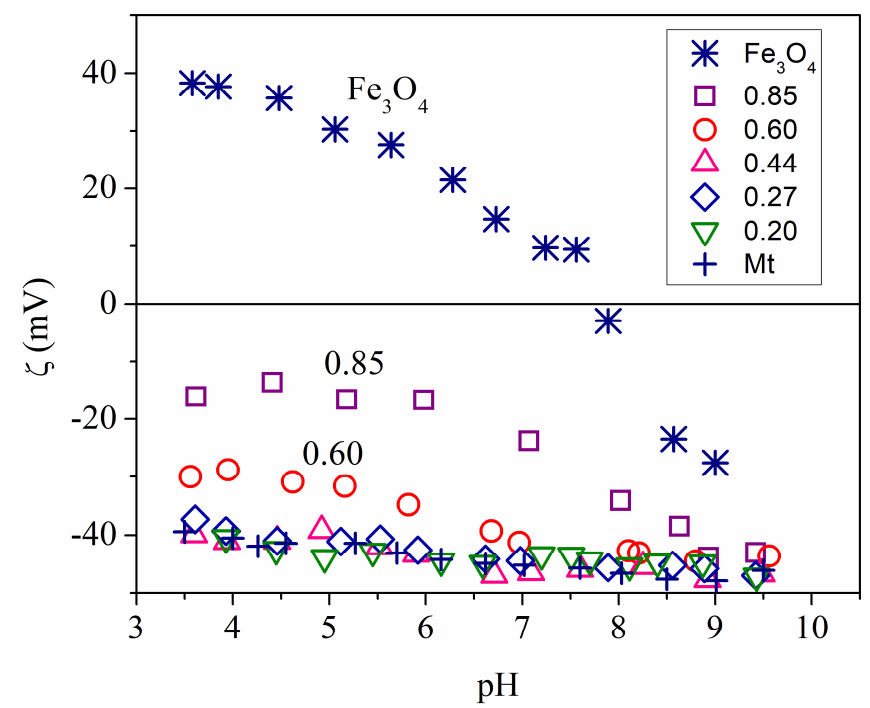

Figure 3. Zeta potential vs. $\mathrm{pH}$ data of the different studied solids. F values are given in the graph.

The Zetasizer equipment allowed us, in addition to measuring the mean value of $\zeta$, to obtain information of the distribution of $\zeta$ in each measurement. Since most of the samples studied in this work are mixtures of two solids, and the electrokinetic behavior 
of these two solids is very different, measuring the distribution of $\zeta$ at any given $\mathrm{pH}$ permits deducing whether the particles of the two solids remained as two independent populations in the suspension or they became grouped, generating co-aggregates with intermediate properties. Figure 4 shows the $\zeta$ distributions of the different mixtures. For clarity, only distributions corresponding to measurements performed at $\mathrm{pH} 4.5 \pm 0.1$ are shown. The remaining measurements for the different mixtures, in the entire $\mathrm{pH}$ range studied, rendered similar distributions to those of Figure 4, and some examples are shown in the Supplementary Materials. All mixtures had unimodal distributions, just like Mt and $\mathrm{Fe}_{3} \mathrm{O}_{4}$. The mean $\zeta$ values and the standard deviations $(\zeta \pm \mathrm{sd})$ were as follows: $\mathrm{Mt},-41.4 \pm 4.6 \mathrm{mV} ; \mathrm{Mt}-\mathrm{Fe}_{3} \mathrm{O}_{4(0.20)},-42.5 \pm 4.2 \mathrm{mV} ; \mathrm{Mt}-\mathrm{Fe}_{3} \mathrm{O}_{4(0.44)},-38.2 \pm 4.5 \mathrm{mV}$; $\mathrm{Mt}-\mathrm{Fe}_{3} \mathrm{O}_{4(0.60)},-25.9 \pm 4.2 \mathrm{mV} ; \mathrm{Mt}-\mathrm{Fe}_{3} \mathrm{O}_{4(0.85)},-13.6 \pm 4.8 \mathrm{mV} ; \mathrm{Fe}_{3} \mathrm{O}_{4}, 35.7 \pm 4.3 \mathrm{mV}$. Mean $\zeta$ values followed the regular trend observed in Figure 3, with Mt and mixtures with low $\mathrm{F}$ showing high negative $\zeta$, mixtures with high $\mathrm{F}$ showing lower negative $\zeta$, and $\mathrm{Fe}_{3} \mathrm{O}_{4}$ having a positive $\zeta$. All samples, whether pure samples or mixtures, presented unimodal distributions with very similar standard deviations, proving that the moving entities during electrophoretic mobility measurements were single populations of "particles" (more precisely, co-aggregates of particles), with rather homogeneous electrokinetic properties. No evidence for the presence of two different populations of moving entities was obtained. These co-aggregates spontaneously formed when $\mathrm{Mt}$ and magnetite suspensions were mixed, likely driven by the electrostatic attraction between the oppositely charged surfaces or the solids.

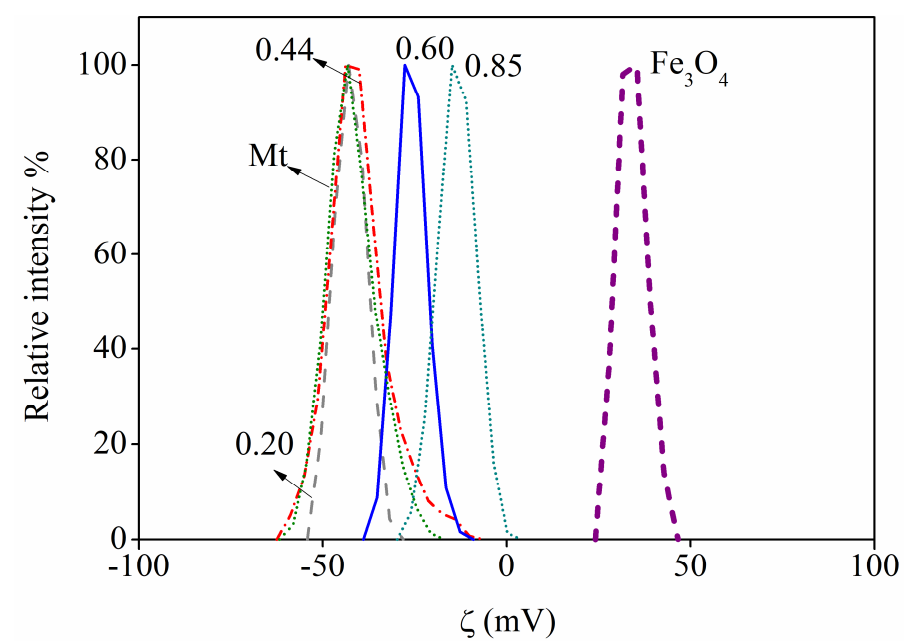

Figure 4. Zeta potential distributions of $\mathrm{Mt}, \mathrm{Fe}_{3} \mathrm{O}_{4}$, and selected $\mathrm{Mt}-\mathrm{Fe}_{3} \mathrm{O}_{4}$ mixtures at $\mathrm{pH}$ 4.5. F values are given in the graph.

Figure 5 shows a series of photographs taken at different times in order to observe the effect caused by an $\mathrm{Nd}$ magnet near each $\mathrm{Mt}-\mathrm{Fe}_{3} \mathrm{O}_{4}$ mixture. This figure provides a semiquantitative idea of their behavior under the influence of an external magnetic field. At time zero, a dark and turbid dispersion was observed. After different magnetization times, the particles cloud (p.c.) became retracted and particles became concentrated on the left side of the tube, in close contact with the magnet. The separation rate depended on the magnetite content, with samples having high F being separated at shorter times. Although there were variations in the separation rates, the solid phases of all mixtures could be readily attracted by the magnet, resulting in clear solutions when the process ended. Again, no evidence for the presence of two different populations of particles or aggregates was found. Knowing that Mt particles in a suspension are not attracted by a magnetic field, the presence of one population of Mt particles and another population of $\mathrm{Fe}_{3} \mathrm{O}_{4}$ particles would have resulted in particle separation under the application of the magnetic field, with $\mathrm{Mt}$ remaining in suspension and $\mathrm{Fe}_{3} \mathrm{O}_{4}$ being attracted by the magnet. These results, in agreement with $\zeta$ measurements, suggest that mixtures were formed by 
rather homogeneous co-aggregates of particles. In each mixture, the co-aggregates had similar magnetic properties, moving all together under the influence of the magnetic field.

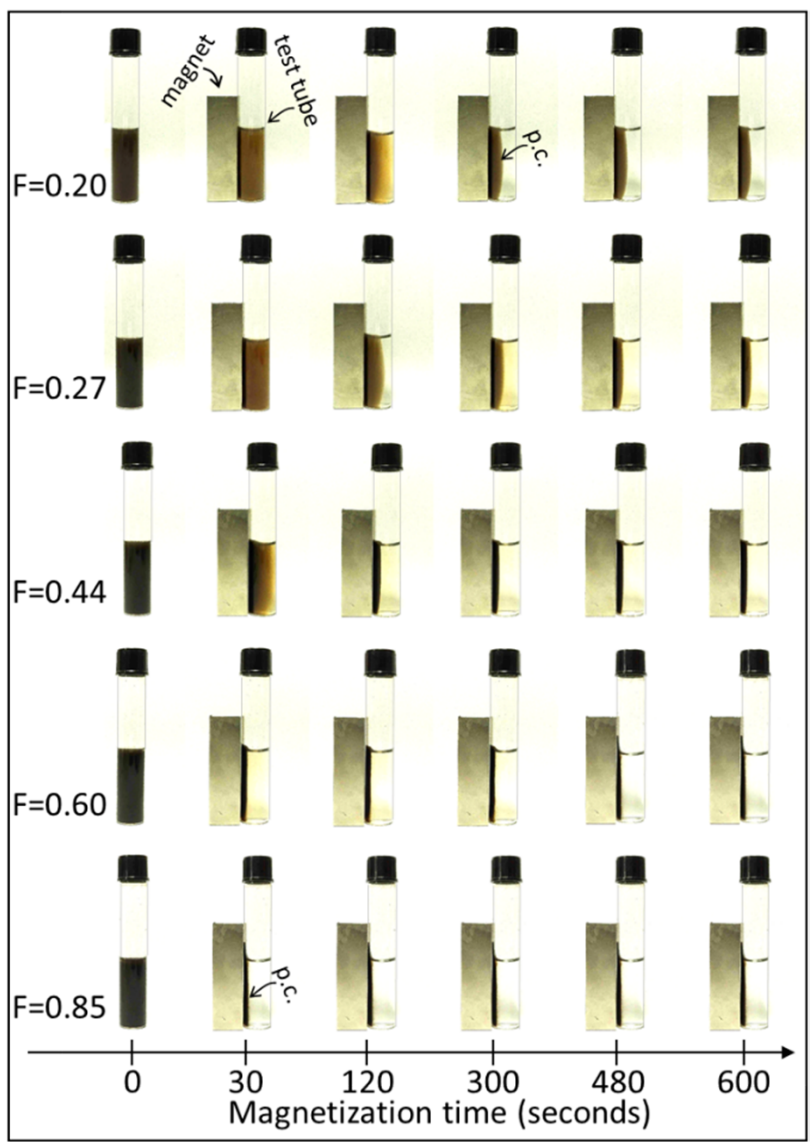

Figure 5. Photographs of capped test tubes with dispersions of $\mathrm{Mt}-\mathrm{Fe}_{3} \mathrm{O}_{4}$ mixtures of different composition under the effect of a magnetic field. Each row represents one dispersion (with the corresponding F value indicated on the left side of the row) after different magnetization times. The zero time corresponds to dispersions before magnetization. Other time values correspond to the time elapsed after placing the magnet in contact with the tubes. It is seen that the particle cloud (p.c.) becomes contracted and attracted by the magnet as time increases.

\subsection{Adsorption Studies}

Figure 6 shows $\mathrm{MB}^{+}$and $\mathrm{As}(\mathrm{V})$ adsorption on $\mathrm{Mt}-\mathrm{Fe}_{3} \mathrm{O}_{4}$ mixtures, for a constant initial concentration of both adsorbates (adsorption percentages are shown as Supplementary Materials). The adsorption of $\mathrm{MB}^{+}$per gram of $\mathrm{Mt}-\mathrm{Fe}_{3} \mathrm{O}_{4}$ decreased linearly with $\mathrm{F}$, becoming zero at $\mathrm{F}=1$ (Figure 6a). However, upon expressing these same results as adsorption of $\mathrm{MB}^{+}$per gram of $\mathrm{Mt}$ in each mixture, a constant adsorption was obtained (Figure $6 \mathrm{~b}$ ). It is evident that $\mathrm{MB}^{+}$adsorbed only on montmorillonite, and that the presence of magnetite did not affect the adsorbing properties of the clay. An analogous behavior was observed with $\mathrm{As}(\mathrm{V})$. The adsorption of $\mathrm{As}(\mathrm{V})$ per gram of $\mathrm{Mt}-\mathrm{Fe}_{3} \mathrm{O}_{4}$ increased linearly with $\mathrm{F}$, being zero at $\mathrm{F}=0$ (Figure 6c). However, plotting the same results as adsorption of $\mathrm{As}(\mathrm{V})$ per gram of magnetite led to a constant adsorption (Figure 6d). It follows, then, that As (V) was only adsorbed on magnetite, and that the presence of Mt did not affect the adsorbing properties of the oxide. 

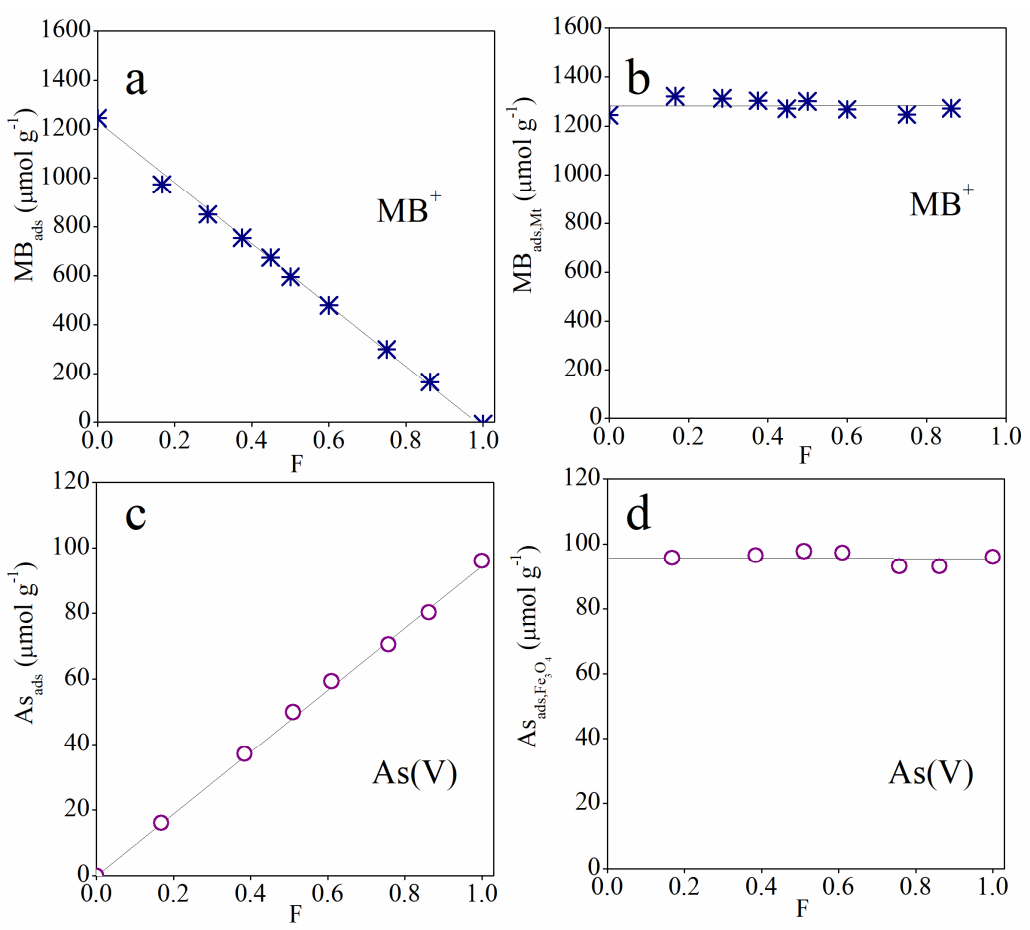

Figure 6. $\mathrm{MB}^{+}(\mathbf{a}, \mathbf{b})$ and $\mathrm{As}(\mathrm{V})(\mathbf{c}, \mathbf{d})$ adsorption on $\mathrm{Mt}-\mathrm{Fe}_{3} \mathrm{O}_{4}$ mixtures as a function of composition. Initial concentration of $\mathrm{MB}^{+}=2 \times 10^{-4} \mathrm{M}$ and $\mathrm{As}(\mathrm{V})=1.6 \times 10^{-4} \mathrm{M}$. Adsorption results are expressed on a per gram of $\mathrm{Mt}-\mathrm{Fe}_{3} \mathrm{O}_{4}$ basis (left panels) or a per gram of $\mathrm{Mt}$ or $\mathrm{Fe}_{3} \mathrm{O}_{4}$ basis (right panels).

The results obtained for one initial concentration of $\mathrm{MB}^{+}$and $\mathrm{As}(\mathrm{V})$ were extended to the full range of concentrations investigated, by means of adsorption isotherms (adsorption percentages are shown in the Supplementary Materials). Figure 7a shows $\mathrm{MB}^{+}$adsorption isotherms on $\mathrm{Mt}, \mathrm{Fe}_{3} \mathrm{O}_{4}$, and $\mathrm{Mt}-\mathrm{Fe}_{3} \mathrm{O}_{4}$ mixtures with $\mathrm{F}$ values 0.2, 0.6, and 0.85. $\mathrm{Mt}$ was the best $\mathrm{MB}^{+}$adsorbent at all concentrations. $\mathrm{Mt}-\mathrm{Fe}_{3} \mathrm{O}_{4}$ mixtures, on the other hand, adsorbed $\mathrm{MB}^{+}$, but their adsorption capacity decreased as the proportion of $\mathrm{Mt}$ in the mixture decreased. Lastly, $\mathrm{Fe}_{3} \mathrm{O}_{4}$ did not adsorb the dye. Therefore, the general results of Figure $7 \mathrm{a}$ shows that the $\mathrm{MB}^{+}$adsorption per gram of mixture strongly depended on the Mt content. Moreover, expressing these same results as adsorption of $\mathrm{MB}^{+}$per gram of $\mathrm{Mt}$ in each mixture (Figure $7 \mathrm{~b}$ ) resulted in a single isotherm, which coincided with the isotherm of pure $\mathrm{Mt}$, within experimental error. It is then evident that $\mathrm{MB}^{+}$adsorption was mainly controlled by montmorillonite at all $\mathrm{MB}^{+}$concentrations, and that the presence of magnetite did not appreciably affect the adsorption capacity of $\mathrm{Mt}$.

Analogously, for the case of As(V), Figure 7c shows the adsorption isotherms on Mt, $\mathrm{Fe}_{3} \mathrm{O}_{4}$, and $\mathrm{Mt}-\mathrm{Fe}_{3} \mathrm{O}_{4}$ mixtures. The opposite behavior to that shown by Figure 7a was observed. Mt did not appreciably adsorb $\mathrm{As}(\mathrm{V})$, but $\mathrm{Fe}_{3} \mathrm{O}_{4}$ was the best adsorbent of the oxoanion. $\mathrm{Mt}-\mathrm{Fe}_{3} \mathrm{O}_{4}$ mixtures were in line with these results, increasing $\mathrm{As}(\mathrm{V})$ adsorption as the proportion of $\mathrm{Fe}_{3} \mathrm{O}_{4}$ in the mixture increased. Figure $7 \mathrm{~d}$ replots the data, expressing the same results of Figure $7 \mathrm{c}$ as adsorption of $\mathrm{As}(\mathrm{V})$ per gram of $\mathrm{Fe}_{3} \mathrm{O}_{4}$ in each mixture. All isotherms nearly merged into a single isotherm, which coincided with the isotherm of pure $\mathrm{Fe}_{3} \mathrm{O}_{4}$. It is clear then that $\mathrm{As}(\mathrm{V})$ adsorption was mainly controlled by magnetite at all oxoanion concentrations, and that the presence of Mt did not significantly affect the adsorption capacity of magnetite. 

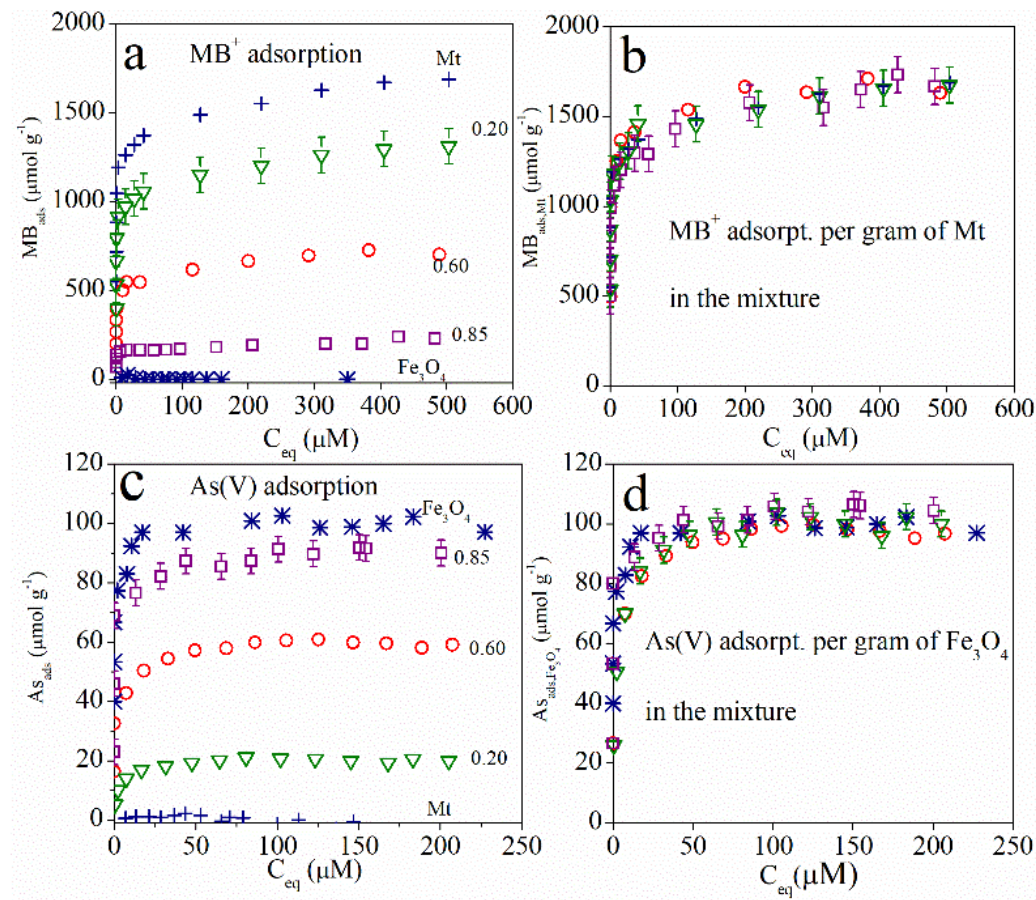

Figure 7. $\mathrm{MB}^{+}(\mathbf{a}, \mathbf{b})$ and $\mathrm{As}(\mathrm{V})(\mathbf{c}, \mathbf{d})$ adsorption isotherms on $\mathrm{Mt}, \mathrm{Fe}_{3} \mathrm{O}_{4}$, and $\mathrm{Mt}-\mathrm{Fe}_{3} \mathrm{O}_{4}$ mixtures ( $F$ values indicated in the graphs). Adsorption results are expressed per gram of $\mathrm{Mt}-\mathrm{Fe}_{3} \mathrm{O}_{4}(\mathbf{a}, \mathbf{c})$, per gram of $\mathrm{Mt}(\mathbf{b})$, or per gram of $\mathrm{Fe}_{3} \mathrm{O}_{4}(\mathbf{d})$. Symbols in b and d are the same as in a and c, respectively. Error bars ( $\pm 2 \mathrm{sd})$ are placed only in selected curves for clarity.

The behaviors of pure $\mathrm{Mt}$ and $\mathrm{Fe}_{3} \mathrm{O}_{4}$ observed in Figure 7a,c are known and expected. Montmorillonite is a very good adsorbent of $\mathrm{MB}^{+}$[23], and it was reported to be a bad adsorbent of $\mathrm{As}(\mathrm{V})[37,38]$. On the other hand, the adsorption of $\mathrm{As}(\mathrm{V})$ by magnetite was similar to that informed previously [22,39]. Structural negative charges on Mt drive the adsorption of $\mathrm{MB}^{+}$but hinder the adsorption of aqueous $\mathrm{As}(\mathrm{V})$ species, which are negatively charged. Functional groups at the magnetite surface allow surface complexation of $\mathrm{As}(\mathrm{V})$ species, but positive surface charges hinder the uptake of $\mathrm{MB}^{+}$. In addition, the behavior of the mixtures and the fact that all isotherms merged into single isotherms are a strong indication that the solid components of $\mathrm{Mt}-\mathrm{Fe}_{3} \mathrm{O}_{4}$ mixtures acted independently as adsorbents in the whole range of $\mathrm{MB}^{+}$and $\mathrm{As}(\mathrm{V})$ concentrations investigated. In other words, $\mathrm{MB}^{+}$adsorption on $\mathrm{Mt}-\mathrm{Fe}_{3} \mathrm{O}_{4}$ mixtures was fully controlled by the content of $\mathrm{Mt}$, while the adsorption of $\mathrm{As}(\mathrm{V})$ was entirely controlled by the content of $\mathrm{Fe}_{3} \mathrm{O}_{4}$. The presence of $\mathrm{Fe}_{3} \mathrm{O}_{4}$ did not affect the adsorption of the dye by $\mathrm{Mt}$ in the mixtures, whereas the presence of $\mathrm{Mt}$ did not affect the adsorption of the oxoanion by $\mathrm{Fe}_{3} \mathrm{O}_{4}$.

The independent behavior of montmorillonite and magnetite in the mixtures is a desired property that facilitates the use of the solids as adsorbents. Indeed, the $\mathrm{MB}^{+}$and $\mathrm{As}(\mathrm{V})$ adsorption capacity could be easily tuned by controlling the proportion of $\mathrm{Mt}$ and $\mathrm{Fe}_{3} \mathrm{O}_{4}$ in the mixture. This independent behavior, nevertheless, does not imply that magnetite particles and montmorillonite particles remain as two independent populations in the suspension. Electrophoretic mobilities and experiments with the magnet demonstrated that $\mathrm{Mt}$ and magnetite form co-aggregates; a schematic picture of one of these co-aggregates is shown in Figure 8. The scheme is based on the following findings and known information: (a) each $\mathrm{Mt}-\mathrm{Fe}_{3} \mathrm{O}_{4}$ co-aggregate consists of a mixture of $\mathrm{Mt}$ and $\mathrm{Fe}_{3} \mathrm{O}_{4}$ particles, with the former adsorbing $\mathrm{MB}^{+}$and the later adsorbing $\mathrm{As}(\mathrm{V})$. This spontaneous co-aggregation is likely driven by the opposite charges of montmorillonite and magnetite, allowing direct contact between the two types of surfaces. Other evidence for the Mt-magnetite interaction is given by the XRD data, which suggest that the piling of Mt layers was modified by the presence of magnetite; (b) magnetite particles were spherical, with a diameter of around $12 \mathrm{~nm}$, around ten times larger than the thickness of Mt layers (the side view of the layers 
is drawn in the figure); (c) since delamination of Mt took place, only piling of a few (2-4) layers was allowed in the drawing; $(\mathrm{d}) \mathrm{As}(\mathrm{V})$ adsorbed on the surface of magnetite and $\mathrm{MB}^{+}$ on the surface and interlayer of Mt. Each aggregate, in addition, possesses electrokinetic and magnetic properties that are like those of the other aggregates and, thus, all move together under the application of an electric or a magnetic field. This is another desired and sound property of the mixtures. They can be easily recovered after acting as adsorbent by applying an electric or a magnetic field, capturing the pollutants and leaving a clear and uncontaminated solution.

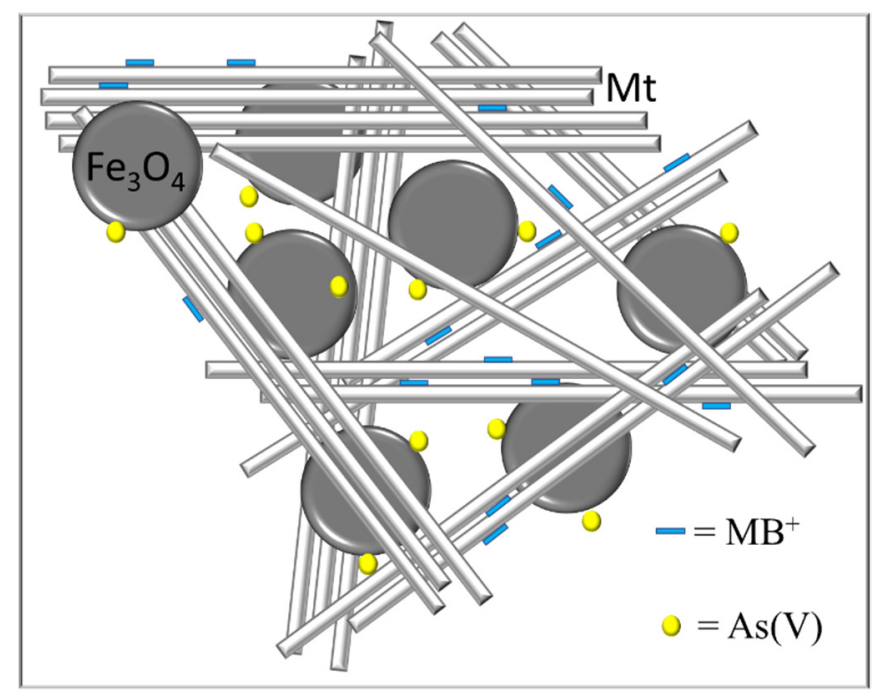

Figure 8. Representative scheme of $\mathrm{Mt}-\mathrm{Fe}_{3} \mathrm{O}_{4}$ co-aggregates, with adsorbed $\mathrm{MB}^{+}$and $\mathrm{As}(\mathrm{V})$. $\mathrm{Mt}$ layers are seen from a side view.

\section{Conclusions}

The simple mix of stock suspensions of montmorillonite and magnetite led to the spontaneous formation of co-aggregates consisting of a mixture of montmorillonite and magnetite particles. The co-aggregates formed at all investigated proportions of the solids and acquired magnetic properties in all cases. The aggregates behaved as stable entities with unimodal $\zeta$ distribution and could be easily removed by the application of an external magnetic field, leaving a clear supernatant. In each co-aggregate, the clay and the oxide acted independently of the other component, regarding adsorption of $\mathrm{MB}^{+}$and $\mathrm{As}(\mathrm{V})$, making it easy to tune the adsorptive properties of the system by controlling the composition of the co-aggregates.

Supplementary Materials: The following are available online at https:/ /www.mdpi.com/article/10 $.3390 / \mathrm{min} 11090927 / \mathrm{s} 1$, Tables S1-S6. Detail of $\mathrm{Mt}_{-}-\mathrm{Fe}_{3} \mathrm{O}_{4}$ mixtures preparation for adsorption studies using $\mathrm{Mt}$ stock suspension $(12.8 \mathrm{~g} / \mathrm{L}), \mathrm{Fe}_{3} \mathrm{O}_{4}$ stock suspension $(7.5 \mathrm{~g} / \mathrm{L}), \mathrm{MB}^{+}$stock solution $(0.001 \mathrm{M})$ and $\mathrm{As}(\mathrm{V})$ stock solution $(0.001 \mathrm{M})$. Figure $\mathrm{S} 1$. Examples of unimodal distributions of zeta potentials at different $\mathrm{pH}$ for the $\mathrm{Mt}_{-} \mathrm{Fe}_{3} \mathrm{O}_{4(0.20)}$ mixture. Figure S2. Examples of unimodal distributions of zeta potentials at different $\mathrm{pH}$ for the $\mathrm{Mt}^{-\mathrm{Fe}_{3}} \mathrm{O}_{4(0.60)}$ mixture. Figure $\mathrm{S} 3$. Examples of unimodal distributions of zeta potentials at different $\mathrm{pH}$ for the $\mathrm{Mt}_{-} \mathrm{Fe}_{3} \mathrm{O}_{4(0.85)}$ mixture. Figure $\mathrm{S}_{4} \mathrm{MB}^{+}$and $\mathrm{As}(\mathrm{V})$ adsorption and adsorption percentages on $\mathrm{Mt}-\mathrm{Fe}_{3} \mathrm{O}_{4}$ mixtures as a function of composition. Initial concentration of: $\mathrm{MB}^{+}, 2 \times 10^{-4} \mathrm{M} ; \mathrm{As}(\mathrm{V}), 1.6 \times 10^{-4} \mathrm{M}$. Same data as Figure 6 in main text. Figure S5. Adsorption percentages of $\mathrm{MB}^{+}$on $\mathrm{Mt}_{-}-\mathrm{Fe}_{3} \mathrm{O}_{4}$ mixtures for the case of adsorption isotherms shown in Figure 7 (main text). Figure S6. Adsorption percentages of As(V) on $\mathrm{Mt}^{-} \mathrm{Fe}_{3} \mathrm{O}_{4}$ mixtures for the case of adsorption isotherms shown in Figure 7 (main text). The behavior is typical for adsorption isotherms performed at different initial concentration of the adsorptive and constant solid dosage ("concentration" of solid). The higher the initial concentration, the lower the adsorption percentage, because the surface is becoming progressively saturated. 
Author Contributions: Conceptualization, E.P. and M.A.; methodology, E.P. and M.A.; validation, E.P.; formal analysis, E.P. and M.A; investigation, E.P.; resources, M.A.; writing-original draft preparation, E.P.; writing—review and editing, M.A.; visualization, E.P. and M.A; supervision, M.A.; project administration, M.A.; funding acquisition, M.A. Both authors have read and agreed to the published version of the manuscript.

Funding: This research was founded by SGCyT-UNS, grant number PGI 24/Q083, ANPCYTMINCYT, grant number PICT 2018/03592 and CONICET, grant numbers 11220150100769CO, $23820190100022 \mathrm{CO}$ and $20720150100031 \mathrm{CO}$.

Acknowledgments: The authors would like to thank SGCyT-UNS (PGI), ANPCYT-MINCYT (PICT), and CONICET (PIP-PIO). This work is also part of the Joint Project CONICET (Argentina)NSFC (China).

Conflicts of Interest: The authors declare no conflict of interest.

\section{References}

1. Filik, H.; Avan, A.A. Magnetic Nanostructures for Preconcentration, Speciation and Determination of Chromium Ions: A Review. Talanta 2019, 203, 168-177. [CrossRef]

2. Karimi, M.A.; Mohadesi, A.; Hatefi-Mehrjardi, A.; Mohammadi, S.Z.; Yarahmadi, J.; Khayrkhah, A. Separation/Preconcentration and Speciation Analysis of Trace Amounts of Arsenate and Arsenite in Water Samples Using Modified Magnetite Nanoparticles. J. Chem. 2014, 2014. [CrossRef]

3. Cao, Y.; Sheng, T.; Yang, Z.; Huang, D.; Sheng, L. Synthesis of Molecular-Imprinting Polymer Coated Magnetic Nanocomposites for Selective Capture and Fast Removal of Environmental Tricyclic Analogs. Chem. Eng. J. 2021, 426, 128678. [CrossRef]

4. Peighambardoust, S.J.; Foroutan, R.; Peighambardoust, S.H.; Khatooni, H.; Ramavandi, B. Decoration of Citrus Limon Wood Carbon with $\mathrm{Fe}_{3} \mathrm{O}_{4}$ to Enhanced $\mathrm{Cd}^{2+}$ Removal: A Reclaimable and Magnetic Nanocomposite. Chemosphere 2021, $282,131088$. [CrossRef]

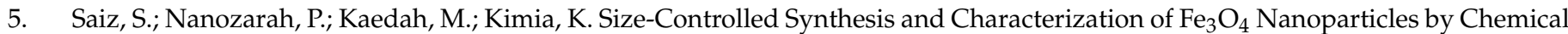
Coprecipitation Method. Sains Malays. 2008, 37, 389-394.

6. Jang, J.; Lee, D.S. Magnetite Nanoparticles Supported on Organically Modified Montmorillonite for Adsorptive Removal of Iodide from Aqueous Solution: Optimization Using Response Surface Methodology. Sci. Total Environ. 2018, 615, 549-557. [CrossRef]

7. Shattar, S.F.A.; Zakaria, N.A.; Foo, K.Y. Utilization of Montmorillonite as a Refining Solution for the Treatment of Ametryn, a Second Generation of Pesticide. J. Environ. Chem. Eng. 2017, 5, 3235-3242. [CrossRef]

8. Wang, G.; Hua, Y.; Su, X.; Komarneni, S.; Ma, S.; Wang, Y. Cr(VI) Adsorption by Montmorillonite Nanocomposites. Appl. Clay Sci. 2016, 124, 111-118. [CrossRef]

9. Geroeeyan, A.; Niazi, A.; Konoz, E. Removal of Basic Orange 2 Dye and $\mathrm{Ni}^{2+}$ from Aqueous Solutions Using Alkaline-Modified Nanoclay. Water Sci. Technol. 2021, 83, 2271-2286. [CrossRef]

10. Jeganathan, M.; Dhakshinamoorthy, A.; Pitchumani, K. One-Pot Synthesis of 2-Substituted Quinoxalines Using K10Montmorillonite as Heterogeneous Catalyst. Tetrahedron Lett. 2014, 55, 1616-1620. [CrossRef]

11. Suresh, D.; Dhakshinamoorthy, A.; Pitchumani, K. A Green Route for the Synthesis of 2-Substituted Benzoxazole Derivatives Catalyzed by $\mathrm{Al}^{3+}$-Exchanged K10 Clay. Tetrahedron Lett. 2013, 54, 6415-6419. [CrossRef]

12. Bharath, G.; Alhseinat, E.; Ponpandian, N.; Khan, M.A.; Siddiqui, M.R.; Ahmed, F.; Alsharaeh, E.H. Development of Adsorption and Electrosorption Techniques for Removal of Organic and Inorganic Pollutants from Wastewater Using Novel Magnetite/Porous Graphene-Based Nanocomposites. Sep. Purif. Technol. 2017, 188, 206-218. [CrossRef]

13. Su, C. Environmental Implications and Applications of Engineered Nanoscale Magnetite and Its Hybrid Nanocomposites: A Review of Recent Literature. J. Hazard. Mater. 2017, 322, 48-84. [CrossRef]

14. Galindo-González, C.; de Vicente, J.; Ramos-Tejada, M.M.; López-López, M.T.; González-Caballero, F.; Durán, J.D.G. Preparation and Sedimentation Behavior in Magnetic Fields of Magnetite-Covered Clay Particles. Langmuir 2005, 21, 4410-4419. [CrossRef]

15. Mamedov, A.; Ostrander, J.; Aliev, F.; Kotov, N.A. Stratified Assemblies of Magnetite Nanoparticles and Montmorillonite Prepared by the Layer-by-Layer Assembly. Langmuir 2000, 16, 3941-3949. [CrossRef]

16. Yuan, P.; Fan, M.; Yang, D.; He, H.; Liu, D.; Yuan, A.; Zhu, J.; Chen, T. Montmorillonite-Supported Magnetite Nanoparticles for the Removal of Hexavalent Chromium [Cr(VI)] from Aqueous Solutions. J. Hazard. Mater. 2009, 166, 821-829. [CrossRef]

17. Larraza, I.; López-Gónzalez, M.; Corrales, T.; Marcelo, G. Hybrid Materials: Magnetite-Polyethylenimine-Montmorillonite, as Magnetic Adsorbents for Cr(VI) Water Treatment. J. Colloid Interface Sci. 2012, 385, 24-33. [CrossRef]

18. Zhao, G.; Wang, J.; Li, Y.; Chen, X.; Liu, Y. Enzymes Immobilized on Superparamagnetic $\mathrm{Fe}_{3} \mathrm{O}_{4} @$ Clays Nanocomposites: Preparation, Characterization, and a New Strategy for the Regeneration of Supports. J. Phys. Chem. C 2011, 115, 6350-6359. [CrossRef] 
19. Cabrera, M.; Maciel, J.C.; Quispe-Marcatoma, J.; Pandey, B.; Neri, D.F.M.; Soria, F.; Baggio-Saitovitch, E.; de Carvalho, L.B. Magnetic Composites from Minerals: Study of the Iron Phases in Clay and Diatomite Using Mössbauer Spectroscopy, Magnetic Measurements and XRD. Hyperfine Interact. 2014, 224, 197-204. [CrossRef]

20. Oliveira, L.C.A.; Rios, R.V.R.A.; Fabris, J.D.; Sapag, K.; Garg, V.K.; Lago, R.M. Clay-Iron Oxide Magnetic Composites for the Adsorption of Contaminants in Water. Appl. Clay Sci. 2003, 22, 169-177. [CrossRef]

21. Lombardi, B.; Baschini, M.; Torres Sánchez, R.M. Bentonite Deposits of Northern Patagonia. Appl. Clay Sci. 2003, 22, 309-312. [CrossRef]

22. Pecini, E.M.; Springer, V.; Brigante, M.; Avena, M. Arsenate Interaction with the Surface of Nanomagnetic Particles. High Adsorption or Full Release. J. Environ. Chem. Eng. 2017, 5, 4917-4922. [CrossRef]

23. Pecini, E.M.; Avena, M.J. Measuring the Isoelectric Point of the Edges of Clay Mineral Particles: The Case of Montmorillonite. Langmuir 2013, 29, 14926-14934. [CrossRef] [PubMed]

24. Lenoble, V.; Deluchat, V.; Serpaud, B.; Bollinger, J.C. Arsenite Oxidation and Arsenate Determination by the Molybdene Blue Method. Talanta 2003, 61, 267-276. [CrossRef]

25. Oueslati, W.; Ben Rhaiem, H.; Lanson, B.; Ben Haj Amara, A. Selectivity of Na-Montmorillonite in Relation with the Concentration of Bivalent Cation $\left(\mathrm{Cu}^{2+}, \mathrm{Ca}^{2+}, \mathrm{Ni}^{2+}\right)$ by Quantitative Analysis of XRD Patterns. Appl. Clay Sci. 2009, 43, 224-227. [CrossRef]

26. Chen, G.; Han, B.; Yan, H. Interaction of Cationic Surfactants with Iron and SodiumMontmorillonite Suspensions. J. Colloid Interface Sci. 1998, 201, 158-163. [CrossRef]

27. Farmer, V.C. The Infrared Spectra of Minerals; Mineralogical Society: Chantilly, VA, USA, 1974; p. 539.

28. Costanzo, P.M. Baseline Studies of the Clay Minerals Society Source Clays: Introduction. Clays Clay Miner. 2001, 49, $372-373$. [CrossRef]

29. Fan, M.; Yuan, P.; Zhu, J.; Chen, T.; Yuan, A.; He, H.; Chen, K.; Liu, D. Core-Shell Structured Iron Nanoparticles Well Dispersed on Montmorillonite. J. Magn. Magn. Mater. 2009, 321, 3515-3519. [CrossRef]

30. Green-Pedersen, H.; Pind, N. Preparation, Characterization, and Sorption Properties for Ni(II) of Iron OxyhydroxideMontmorillonite. Colloids Surf. A Physicochem. Eng. Asp. 2000, 168, 133-145. [CrossRef]

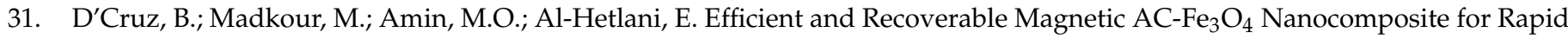
Removal of Promazine from Wastewater. Mater. Chem. Phys. 2020, 240, 122109. [CrossRef]

32. Sondi, I.; Biscan, J.; Pravdic, V. Electrokinetics of Pure Clay Minerals Revisited. J. Colloid Interface Sci. 1996, 178, 514-522. [CrossRef]

33. Guz, L.; Curutchet, G.; Torres Sánchez, R.M.; Candal, R. Adsorption of Crystal Violet on Montmorillonite (or Iron Modified Montmorillonite) Followed by Degradation through Fenton or Photo-Fenton Type Reactions. J. Environ. Chem. Eng. 2014, 2, 2344-2351. [CrossRef]

34. Miller, S.; Low, P. Characterization of the Electrical Double Layer of Montmorillonite. Langmuir 1990, 11, 572-578. [CrossRef]

35. Illés, E.; Tombácz, E. The Effect of Humic Acid Adsorption on pH-Dependent Surface Charging and Aggregation of Magnetite Nanoparticles. J. Colloid Interface Sci. 2006, 295, 115-123. [CrossRef] [PubMed]

36. Favela-Camacho, S.E.; Samaniego-Benítez, E.J.; Godínez-García, A.; Avilés-Arellano, L.M.; Pérez-Robles, J.F. How to Decrease the Agglomeration of Magnetite Nanoparticles and Increase Their Stability Using Surface Properties. Colloids Surf. A Physicochem. Eng. Asp. 2019, 574, 29-35. [CrossRef]

37. Luengo, C.; Puccia, V.; Avena, M. Arsenate Adsorption and Desorption Kinetics on a Fe(III)-Modified Montmorillonite. J. Hazard. Mater. 2011, 186, 1713-1719. [CrossRef]

38. Ren, X.; Zhang, Z.; Luo, H.; Hu, B.; Dang, Z.; Yang, C.; Li, L. Adsorption of Arsenic on Modified Montmorillonite. Appl. Clay Sci. 2014, 97, 17-23. [CrossRef]

39. Akin, I.; Arslan, G.; Tor, A.; Ersoz, M.; Cengeloglu, Y. Arsenic(V) Removal from Underground Water by Magnetic Nanoparticles Synthesized from Waste Red Mud. J. Hazard. Mater. 2012, 235, 62-68. [CrossRef] 